\title{
PENGGUNAAN MODEL PEMBELAJARAN TIME TOKEN TERHADAP PEMAHAMAN KONSEP MATEMATIKA SISWA KELAS VIII SMP
}

\author{
Beni Junedi ${ }^{1}$, Novita Anggiani ${ }^{2}$ \\ ${ }^{1}$ Program Studi Pendidikan Matematika STKIP Insan Madani Airmolek \\ ${ }^{2}$ Mahasiswa Program Studi Pendidikan Matematika STKIP Insan Madani Airmolek \\ ${ }^{1}$ benijunedi040787@gmail.com, ${ }^{2}$ Novitaanggiani@gmail.com
}

\begin{abstract}
This research was motivated by the understanding of mathematical concepts class VIII SMPN 3 Pasir Penyu still low. This study aims to determine student's understanding of mathematical concepts using time token learning model is better than the students understanding of mathematical concepts using convensional learning in class VIII SMPN 3 Pasir Penyu. This study design was randomized control group only design. This study population was students all class VIII, the sample is class $\mathrm{VIII}_{3}$ and VIII. Data were analyzed using test- $t$, analysis result obtained $t_{\text {count }}>t_{\text {table }}$ is $2.995>2.002$, it can be concluded that the understanding of the mathematical concepts of student with the use of time token learning model better than an understanding of the mathematical concepts of students with the use of convensional learning in class SMPN 3 Pasir Penyu.
\end{abstract}

Keywords: Time token, understanding of mathematical concepts.

\begin{abstract}
Abstrak. Penelitian ini dilatarbelakangi oleh pemahaman konsep matematika siswa kelas VIII SMPN 3 Pasir Penyu masih rendah. Penelitian ini bertujuan untuk mengetahui pemahaman konsep matematika siswa menggunakan model pembelajaran time token lebih baik daripada pemahaman konsep matematika siswa dengan menggunakan pembelajaran konvensional kelas VIII SMPN 3 Pasir Penyu. Penelitian ini menggunakan rancangan randomized control group only design. Populasi penelitian ini seluruh siswa kelas VIII, dengan sampel penelitian yaitu kelas $\mathrm{VIII}_{3}$ dan $\mathrm{VIII}_{4}$. Teknik analisis data menggunakan uji-t, hasil analisis diperoleh $\mathrm{t}_{\text {hitung }}$ $>t_{\text {tabel }}$ yaitu $2.995>2.002$, maka dapat disimpulkan bahwa pemahaman konsep matematika siswa dengan penggunaan model pembelajarakn time token lebih baik daripada pemahaman konsep matematika siswa dengan penggunaan pembelajaran konvensional kelas VIII SMPN 3 Pasir Penyu.
\end{abstract}

Kata Kunci: Time token, pemahaman konsep matematika.

\section{PENDAHULUAN}

Berdasarkan hasil pengamatan yang telah dilakukan di Sekolah Menengah Pertama Negeri 3 Pasir Penyu, peneliti menemukan suatu permasalahan yang menyebabkan siswa kesulitan memahami konsep matematika yang telah diberikan oleh guru. Dari hasil pengamatan terlihat hanya sebagian siswa yang aktif dalam menyelesaikan soal/masalah yang diberikan oleh guru, hal ini disebabkan karena pada saat guru menyampaikan materi pembelajaran masih ada siswa yang terkesan malu-malu untuk bertanya kepada guru tentang apa yang belum mereka mengerti, sehingga siswa mengalami kesulitan untuk menyelesaikan permasalahan matematika yang ada. Pada saat guru memberikan suatu pertanyaan hanya siswa-siswa tertentu saja yang berani menjawab sehingga siswa tersebut mendominasi dalam setiap kegiatan. Selain itu, dilihat dari cara siswa menjawab soal matematika, terlihat siswa kurang mampu memahami konsep matematika secara tepat dan benar, hal ini disebabkan karena siswa belum mampu menterjemahkan kalimat pada soal ke dalam notasi ataupun simbol matematika dengan tepat dan siswa juga mengabaikan prinsip terhadap hasil perhitungan yang sangat penting untuk pengukuran.

Berdasarkan permasalahan di atas, peneliti menduga bahwa salah satu cara yang tepat untuk membantu pemahaman konsep matematika siswa menjadi lebih baik adalah dengan menggunakan model pembelajaran time token. Sehingga tujuan dari penelitian ini adalah 
untuk mengetahui pemahaman konsep matematika siswa dengan penggunaan model pembelajaran time token lebih baik daripada pemahaman konsep matematika dengan penggunaan pembelajaran konvensional di kelas VIII Sekolah Menengah Pertama Negeri 3 Pasir Penyu. Model pembelajaran time token merupakan salah satu contoh kecil dari penerapan pembelajaran yang demokratis di sekolah, model ini menjadikan aktivitas siswa menjadi titik perhatian utama. Dengan kata lain mereka selalu dilibatkan secara aktif, guru dapat berperan untuk mengajak siswa mencari solusi bersama terhadap permasalahan yang ditemui (Kurniasih dan Sani, 2015).

Menurut Shoimin (2014) langkah-langkah model pembelajaran time token adalah (1) Guru menjelaskan tujuan pembelajaran. (2) Guru mengkondisikan kelas untuk melaksanakan diskusi (cooperative learning/CL). (3) Guru memberi tugas kepada siswa. (4) Guru memberi sejumlah kupon berbicara dengan waktu \pm 30 detik per kupon pada setiap siswa. (5) Guru meminta siswa menyerahkan kupon berbicara atau memberi komentar. Setiap tampil berbicara satu kupon. Siswa dapat tampil lagi setelah bergiliran dengan siswa lainnya. Siswa yang telah habis kuponnya tak boleh bicara lagi. Siswa yang masih memegang kupon harus bicara sampai semua kuponnya habis. Demikian seterusnya hingga semua anak menyampaikan pendapatnya. (6) Guru memberi sejumlah nilai sesuai waktu yang digunakan tiap siswa.

Penggunaan model time token ini akan membantu pemahaman konsep matematika siswa, adapun Indikator dalam pemahaman konsep dalam penelitian ini yaitu (1) Siswa mampu menyajikan konsep dalam berbagai bentuk representasi matematis. (2) Siswa mampu menggunakan dan memanfaatkan serta memilih prosedur atau operasi tertentu. (3) Siswa mampu mengaplikasikan konsep atau algoritma pada pemecahan masalah.

Sebenarnya secara tidak sadar dalam psoses pembelajaran dengan menggunakan model pembelajaran time token siswa dipaksa untuk aktif dalam diskusi, sehingga siswa mampu bertanya ataupun merespon pertanyaan dari guru. Ketika siswa mampu mengkomunikasikan ide-idenya menggunakan kartu berbicara yang ada di dalam model time token, maka hal ini akan membantu siswa untuk mampu menyajikan konsep ke dalam bentuk representasi matematis, siswa juga akan dibimbing untuk tepat memilih prosedur penyelesaian dan akhirnya siswa juga dapat mengapilkasikan konsep ke dalam pemecahan masalah. Ningzaswati (2015) memperoleh kesimpulan dari hasil penelitian bahwa aktivitas belajar siswa yang belajar dengan pembelajaran kooperatif teknik time token secara signifikan lebih baik daripada siswa yang mengikuti pembelajaran dengan model konvensional. Dengan demikian dapat disimpulkan bahwa dengan menggunakan model pembelajaran time token maka siswa mampu mencapai indikator pemahaman konsep matematika dengan baik.

\section{METODE}

Penelitian ini merupakan jenis penelitian eksperimen yang bertujuan untuk mengungkap hubungan sebab akibat antar variabel, pada penelitian eksperimen terjadi perlakuan atau manipulasi oleh peneliti pada variabel (Sandjaja, 2006). Desain penelitian yang digunakan dalam penelitian ini adalah Quasi Eksperimental (eksperimen semu), dengan rancangan penelitian yaitu randomized control group only design. Terlihat pada tabel berikut. 
Tabel 1. Rancangan Penelitian

\begin{tabular}{lccc}
\cline { 2 - 3 } & Pretest & Treatment & Postetst \\
\hline Experiment Group (R)* & $\mathrm{X}$ & $\mathrm{T}_{2}$ \\
\hline Control Group (R) & & & $\mathrm{T}_{2}$ \\
\hline
\end{tabular}

Sumber: Suryasubrata (2014)

Keterangan:

$\mathrm{X}$ : Variabel perlakuan yaitu model pembelajaran time token

$\mathrm{T}_{2}$ : Variabel pengukuran yaitu tes pemahaman konsep matematika

Dalam rancangan ini sekelompok subjek yang diambil dari populasi tertentu dikelompokkan secara rambang menjadi dua kelompok, yaitu kelompok eksperimen dan kelompok kontrol. Kelompok eksperimen dikenai variabel perlakuan tertentu dalam jangka waktu tertentu, lalu kedua kelompok itu dikenai pengukuran yang sama. Perbedaan yang timbul dianggap bersumber pada variabel perlakuan (Suryabrata, 2014). Instrument penelitian yang digunakan berupa tes uraian yang dilaksanakan diakhir penelitian (posttest), soal tes ini terdiri dari 5 butir soal dan akan diberikan kepada kelas eksperimen dan kelas kontrol pada akhir penelitian. Teknik analisis data yang digunakan dalam penelitian ini adalah uji-t sebagai uji hipotesis dengan uji prasyarat yaitu uji normalitas dan uji homogenitas.

\section{HASIL DAN PEMBAHASAN}

Penelitian ini menggunakan dua kelas sampel yaitu kelas eksperimen dan kelas kontrol, pemilihan sampel diambil secara acak dan yang terpilih menjadi kelas sampel adalah kelas VIII 4 dan yang terpilih menjadi kelas kontrol adalah VIII 3. Kelas eksperimen diberi perlakuan sebagai variabel bebasnya yaitu penggunaan model pembelajaran time token sedangkan variabel terikatnya yaitu pemahaman konsep matematika siswa. Sedangkan pada kelas kontrol tidak diberi perlakuan artinya pelaksanaan pembelajaran dilakukan seperti biasa, dimana peneliti mengajar dengan menggunakan perpaduan metode. Setelah penelitian dilakukan diperoleh data mengenai pemahaman konsep matematika siswa, untuk tahap selanjutnya dilakukan analisis terhadap data yang diperoleh. Analisis data dilakukan untuk mengungkapkan bagaimana pemahaman konsep matematika siswa. Instrumen yang digunakan adalah tes uraian yang dilaksanakan pada akhir penelitian. Pelaksanaan pembelajaran di kelas eksperimen dan kelas kontrol masingmasing terdiri dari 7 kali pertemuan dengan alokasi waktu setiap kali pertemuan yaitu $2 \mathrm{x}$ 40 menit. Setelah dilaksanakan proses pembelajaran, selanjutnya pada akhir penelitian diadakan tes pemahaman konsep matematika siswa. Hasil analisis terhadap data pemahaman konsep matematika siswa selanjutnya dideskripsikan menurut skor tertinggi $\left(\mathrm{X}_{\text {mak }}\right)$, skor terendah $\left(\mathrm{X}_{\min }\right)$, rata-rata $(\bar{X})$, dan simpangan baku $(\mathrm{S})$. Deskripsi data pemahaman konsep matematika kelas eksperimen dan kelas kontrol disajikan pada tabel berikut.

Tabel 2. Deskripsi Data Pemahaman Konsep Matematika Siswa

\begin{tabular}{ccc}
\hline Deskripsi & Kelas Eskperimen & Kelas Kontrol \\
\hline $\mathrm{N}$ & 30 & 30 \\
\hline Skor Ideal & 20 & 20 \\
\hline $\mathrm{X}_{\operatorname{maks}}$ & 20 & 19 \\
\hline $\mathrm{X}_{\min }$ & 10 & 5 \\
\hline $\bar{X}$ & 17,03 & 15,03 \\
\hline$S$ & 2,34 & 2,81 \\
\hline
\end{tabular}


Berdasarkan Tabel 2 terlihat bahwa skor rata-rata pemahaman konsep matematika siswa kelas eksperimen lebih tinggi dari kelas kontrol yaitu pada kelas eksperimen 17,03 dan pada kelas kontrol 15,03. Ini menunjukkan bahwa kelas eksperimen lebih baik daripada kelas kontrol, artinya data pada kelas eksperimen menyebar mendekati skor 17,03 dan data pada kelas kontrol menyebar mendekati skor 15,03. Selain itu, standar deviasi kelas eksperimen lebih kecil daripada kelas kontrol. Ini menunjukkan bahwa pemahaman konsep matematika siswa kelas eksperimen lebih homogen dan tidak terdapat perbedaan yang sangat jauh antara kelas atas (siswa yang pintar) dengan kelas bawah (siswa yang kurang pintar) bila dibandingkan dengan kelas kontrol.

Berdasarkan deskripsi dan analisis data tes terakhir terlihat bahwa pemahaman konsep matematika pada materi materi bangun ruang sisi datar lebih baik daripada kelas kontrol. Hal ini dapat dilihat dari skor tertinggi, sekor terendah dan nilai rata-rata kelas eksperimen yang jauh lebih baik dari kelas kontrol dan kelas kontrol. Skor tertinggi kelas eksperimen adalah 20 dan skor terendah adalah 10 dengan nilai rata-rata 17,033. Sedangkan pada kelas kontrol yang skor yang tertinggi adalah 19 dan skor terendah adalah 5, dengn nilai rata-rata 15,033. Dengan demikian pemahaman konsep kelas eksperimen lebih baik daripada kelas kontrol, hal ini sesuai dengan hipotesis yang diajukan yaitu: pemahaman konsep matematika siswa dengan penggunaan model pembelajaran time token lebih baik daripada pemahaman konsep matematika siswa dengan penggunaan pembelajaran konvensional di kelas VIII Sekolah Menengah Pertama Negeri 3 Pasir Penyu.

Indikator keberhasilan dalam kemampuan pemahaman konsep matematika siswa yaitu siswa mampu menyajikan konsep dalam berbagai bentuk representasi matematis, siswa mampu menggunakan dan memanfaatkan serta memilih prosedur atau operasi tertentu dan siswa mampu mengaplikasikan konsep atau algoritma pada pemecahan masalah. Dilihat dari indikator keberhasilan, maka penelitian di atas dapat diperkuat dari hasil tes yang dikerjakan oleh siswa, terlihat terdapat perbedaan kemampuan pemahaman konsep matematika siswa antara kelas eksperimen dengan kelas kontrol sehingga dapat memperkuat hasil penelitian bahwa pemahaman konsep matematika siswa di kelas eksperimen lebih baik daripada pemahaman konsep matematika siswa di kelas kontrol. Di bawah ini merupakan hasil jawaban salah satu siswa kelas eksperimen dan kelas kontrol dari hasil jawaban posttest yang telah dikerjakan oleh siswa, adalah sebagai berikut.

Pada tes nomor 3 dengan soal sebagai berikut.

Diketahui luas alas sebuah prisma segiempat adalah $36 \mathrm{~cm}^{2}$. Jika volume prisma adalah $540 \mathrm{~cm}^{3}$. Berapa tinggi prisma tersebut?

Ada beberapa siswa kelas kontrol menjawab seperti berikut.

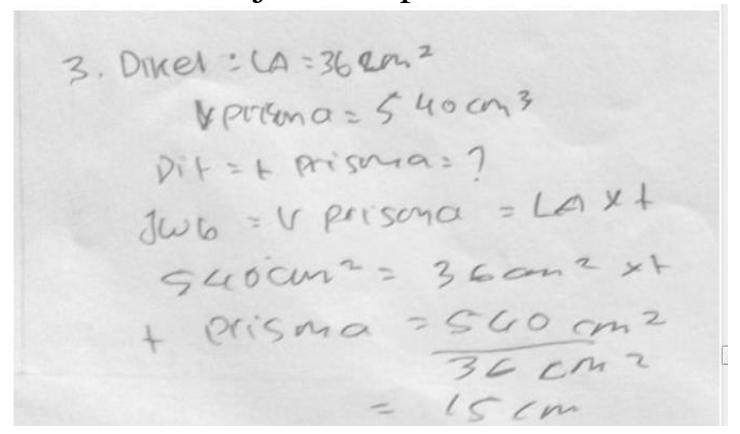

Gambar 1. Penyelesaian Soal Nomor 3 pada Kelas Kontrol

Dari hasil jawaban siswa kelas kontrol di atas, terlihat siswa telah mampu menyajikan konsep ke dalam bentuk representasi matematis, namun siswa ini kurang tepat dalam memanfaatkan rumus sehingga tidak dapat mengaplikasikan konsep ke dalam pemecahan masalah dan mengalami kekeliruan pada satuan volume prisma, hal ini menyebabkan perhitungan selanjutnya menjadi salah. Oleh karena itu dapat dikatakan 
bahwa siswa ini belum dapat mencapai pemahaman konsep matematika dengan baik. Sedangkan pada kelas eksperimen, rata-rata siswa menjawab dengan baik dan benar, sebagian besar siswa pada kelas eksperimen menjawab seperti berikut.

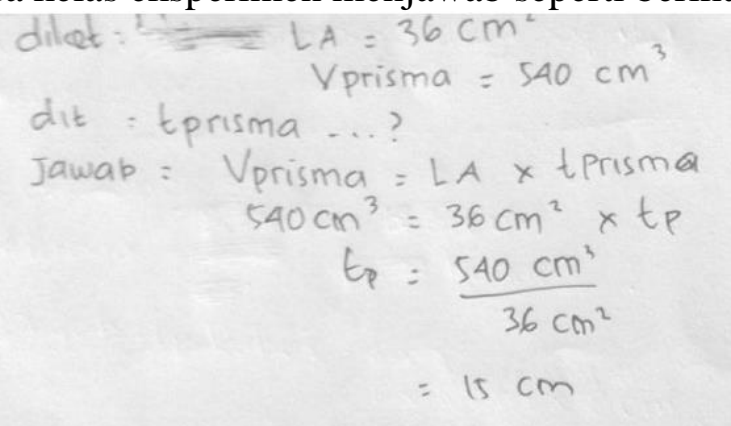

Gambar 2. Penyelesaian Soal Nomor 3 pada Kelas Eksperimen

Dari hasil jawaban yang dikerjakan oleh siswa kelas eksperimen, terlihat siswa telah mampu menyajikan konsep ke dalam representasi matematis. Siswa di kelas eksperimen ini juga tepat dalam memilih dan memanfaatkan rumus, maka berbeda dengan siswa di kelas kontrol, siswa di kelas eksperimen ini sangat tepat dalam mengaplikasikan konsep ke dalam pemecahan masalah dan tidak terjadi kekeliruan pada satuan tinggi prisma. Terlihat siswa mempunyai pemahaman yang sangat baik terhadap soal ini, oleh karena siswa ini dapat menyelesaikan permasalahan secara sistematis dengan menerjemahkan kalimat pada soal ke dalam notasi/simbol matematika, siswa ini juga dapat memilih, memanfaatkan dan mengaplikasikan konsep ke dalam pemecahan masalah dengan baik dan benar, maka dapat dikatakan bahwa siswa ini telah mencapai pemahaman konsep matematika dengan baik.

Aunurrahman (2009:74) berpendapat pemahaman konsep peserta didik merupakan faktor yang sangat penting dalam pelaksanaan pendidikan dan pembelajaran. Jika guru memahami peserta didik dengan baik, maka ia dapat memilih dan menentukan sumbersumber belajar yang tepat, pendekatan-pendekatan yang sesuai, mampu mengatasi semua masalah-masalah pembelajaran sehari-hari dengan baik, sehingga potensi anak dapat didorong untuk mencapai perkembangan yang optimal melalui penyelenggaraan proses pembelajaran. Pemahaman potensi peserta didik merupakan kerangka dasar bagi pemahaman peserta didik secara keseluruhan. Kekeliruan pandangan terhadap eksistensi mereka seringkali menimbulkan dampak yang serius bagi anak.

Hal ini juga didukung oleh hasil penelitian yang relevan yang dilakukan oleh Windi, dkk (2018) bahwa penggunaan model time token dapat meningkatkan pemahaman konsep penjumlahan dan pengurangan bilangan bulat pada siswa kelas IV SDN Kedungrejo 02 Tunjungan Blora dapat dilihat dari presentase ketuntasan belajar siswa menunjukkan pembelajaran sebelum diberi perlakuan menggunakan model pembelajaran time token sebanyak 16 siswa yang tuntas dengan persentase 57,14\% dan 11 siswa yang belum tuntas dengan persentase $39 \%$. Sedangkan setelah diberi perlakuan menggunakan model time token yang tuntas sebanyak 26 siswa dengan persentase $92,86 \%$ dan 2 siswa yang tidak tuntas dengan persentase $7 \%$.

\section{KESIMPULAN DAN SARAN Kesimpulan}

Berdasarkan analisis terhadap temuan hasil penelitian diperoleh rata-rata $(\bar{X})$ skor kelas eksperimen 17.03 dan rata-rata $(\bar{X})$ skor kelas kontrol 15.03. Teknik analisis data yang digunakan adalah uji-t sebagai uji hipotesis, diperoleh $t_{\text {hitung }}=2.995$ dan $t_{\text {tabel }}=$ 2.002 , karena $t_{\text {hitung }}>t_{\text {tabel }}$ yaitu 2.995 $>2.002$, maka $H_{a}$ diterima. Dengan demikian dapat disimpulkan bahwa pemahaman konsep matematika siswa dengan penggunaan 
model pembelajaran time tokenlebih baik daripada pemahaman konsep matematika siswa dengan penggunaan pembelajaran konvensional di kelas VIII Sekolah Menengah Pertama Negeri 3 Pasir Penyu.

\section{Saran}

Setelah melakukan penelitian ini, dapat dikemukakan beberapa saran yang bermanfaat untuk meningkatkan pemahaman konsep matematika siswa, yaitu:

1. Sebaiknya proses pembelajaran dengan menggunakan model pembelajaran time token lebih sering diterapkan, sehingga aktivitas siswa meningkat karena memperoleh suasana belajar yang lain, tidak monoton seperti biasanya.

2. Pengontrolan variabel dalam peneltian ini yang diukur hanya pada aspek pemahaman konsep luas permukaan dan volume, sedangkan aspek lain tidak dikontrol. Bagi peneliti selanjutnya hendaknya melihat pengaruh penggunaan model pembelajaran time token terhadap aspek matematika lainnya.

\section{DAFTAR PUSTAKA}

Aunurrahman. 2009. Belajar Dan Pembelajaran. Bandung: Alfabeta.

Kurniasih, I., Sani, B. 2015. Ragam Pengembangan Model Pembelajaran Untuk Peningkatan Profesionalitas Guru. Kata Pena.

Ningzaswati, M. S. 2015. Pengaruh Model Pembelajaran Kooperatif Teknik Time Token

Terhadap Aktivitas Belajar Dan Hasil Belajar Ipa Siswa Kelas IV SD. Jurnal Pendidikan Dasar, 5(1).

Sandjaja, B. 2006. Panduan Penelitian. Jakarta: Prestasi Pustakarya.

Shoimin, A. 2014. 68 Model Pembelajaran Inovatif dalam Kurikulum 2013. Yogyakarta: Aruzz Media.

Suryabrata, S. 2014. Metode Penelitian. Jakarta: PT RajaGraffindo.

Windi, A. B., dkk. 2018. Keefektifan Model Pembelajaran Time Token Terhadap Pemahaman Konsep Matematika Siswa Kelas IV SDN Kedungrejo 02 Tunjungan Blora. Jurnal Sekolah, 2(4), h. 323-328. 